\section{SCIENTIFIC RESULTS OF THE NATIONAL ANTARCTIC EXPEDITION.}

THE April number of the Geographical Journal contains a series of short papers by members of the Discovery Expedition which may be regarded as forming together a kind of "preliminary report" on the work of the expedition in the Antarctic regions. These papers are five in number; Captain Scott deals

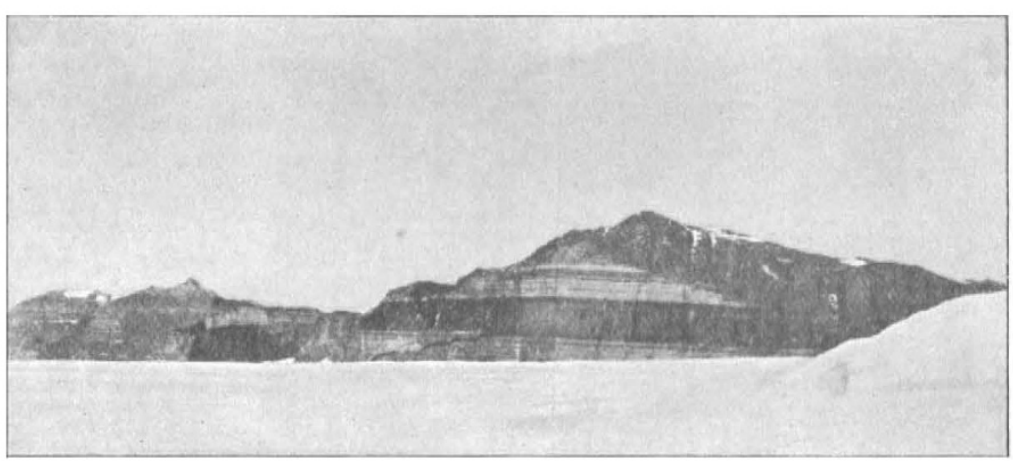

FIG. r. - Beacon Heights. Sandstone and Basalt.

with the general geography, Mr. Ferrar with physical geography, Lieut. Royds with meteorology, Dr. Wilson with seals and birds, and Mr. Hodgson with the marine biological collections. Captain Colbeck also contributes a paper on the Antarctic sea-ice, discussing the observations made on the Southern Cross in $1898-1900$ and on the Morning in I902-4.

Without attempting to summarise the contents of each paper, we may try to indicate what are the chief problems which have attracted the attention of the members of the expedition, and what materials they have provided for their discussion. All things considered, perhaps the most important questions concern the remarkable ice conditions observed by Captain Scott and Mr. Ferrar. "There are innumerable glaciers on the coast of Victoria Land," says Captain Scott, " but the great majority merely discharge local névé fields lying in the valleys of the coastal ranges. Very few run back to the inland ice, and these may be divided into two classesthe living and the dead. In the long stretch of coast between Cape Ada and Mount Longstaff, over I I ${ }^{\circ}$ of latitude, there appears to be only four living ice-discharges from the inland." "The Ferrar glacier is typical of the dead glaciers; the ice lies in the valley practically stationary, and gradually wasting away from the summer thawing." "The Ferrar glacier probably contains as much ice as any hitherto known in the world; the Barne and Shackleton glaciers contain a great deal more, and since they are now in such a diminished state it is interesting to think what vast streams of ice they must have been at their maximum." "To what extent the inland ice sheet stood above its present level is also interesting to surmise; one would submit a possibility of 400 or 500 feet."

NO. I 855 , VOL. 72$]$
Again, referring to the Great Barrier, Captain Scott says :-"... the barrier edge sixty years ago was in advance of its present position, in places as much as 20 or 30 miles."

These facts, along with many others, such as observations by Dr. Wilson and Mr. Ferrar of moraines and erratics high above the level of the icesheet, all go to show that "the majority of curious and often vast ice-formations met with in the Ross sea must be regarded, not as the result of present day conditions, but as the rapidly wasting remnants of a former age."

One of the most remarkable observations is that while, as just explained, the ice from Victoria Land does not make any important contribution to the ice-barrier in the Ross Sea, that ice is moving northward at the rate of about 600 yards in a year. Captain Scott believes that the greater portion of the ice-sheet in the Ross Sea is afloat, and that the high coast line of Victoria Land continues southward in a direction towards Graham's Land. Here there is obviously a fruitful source of discussion, but whatever the result, with regard to the distribution of land and sea, it may be taken as proved beyond doubt that the ice in at least this part of the Antarctic regions is in a state of fairly rapid retreat, and it is known that the same thing is happening in the Arctic regions.

Mr. Ferrar's geological observations in Victoria Land have an important bearing on the problem of the outline of the land mass, as well as great intrinsic

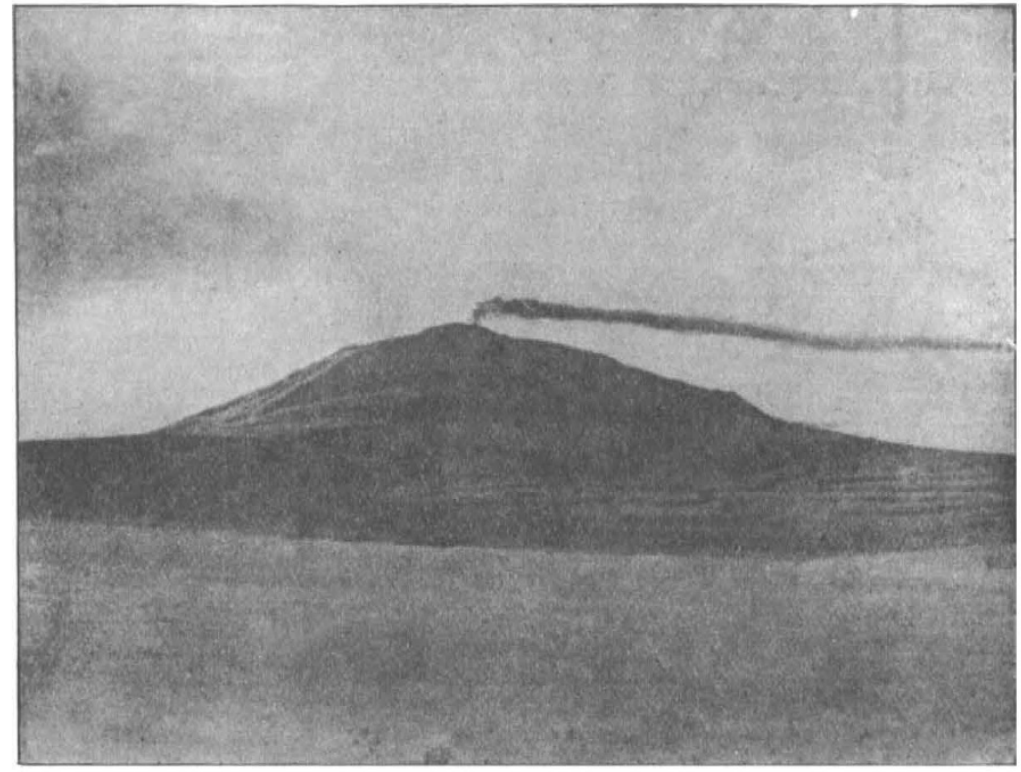

FrG. 2.-Mount Erebus with smok

value. In the Royal Society range a rneissic platform was found, probably of Archæan age, and above it in order are granites, sandstone, and basalt. The granites are, according to Mr. Ferrar, of two ages; the sandstone is 2000 feet thick, while the basalt caps the sandstone, forming plateaux which have been dissected by denudation, and probably also broken up by faulting. At the base of the basalt a thin carbon- 
aceous seam, not more than one-eighth of an inch in thickness, was found. This seam yielded carbonaceous matter which it is agreed must be due to vegetation, but the plant remains are unfortunately beyond identification.

With regard to questions of climate, it is more necessary to await the full discussion of the observations, but a number of interesting points have already cropped up. The smoke from Mount Erebus blew almost persistently to the east, but every record of the Ross Expedition describes it as going to the west. At the Discovery's winter quarters the prevailing winds were southeasterly; the observers are strongly of opinion that this is a local phenomenon. Captain Scott's general conclusions are to the effect that the prevailing direction of the surface winds is west-bysouth throughout the winter, and more southerly during summer; and that there is no snowfall except in the summer and on the rare occasions when the wind blows almost due south. These snow. bearing winds were warm, rising to a temperature of $10^{\circ} \mathrm{C}$. to $15^{\circ} \mathrm{C}$. even in the depth of winter. Their occurrence seems somewhat difficult of explanation, but they obviously have a very important bearing on the relation of temperature and quantity of moisture in causing glacial periods, and modifying their intensity.

In describing the distribution of Antarctic seals, Dr. Wilson records that the Weddell seal was the one most often met with near the land. The expedition

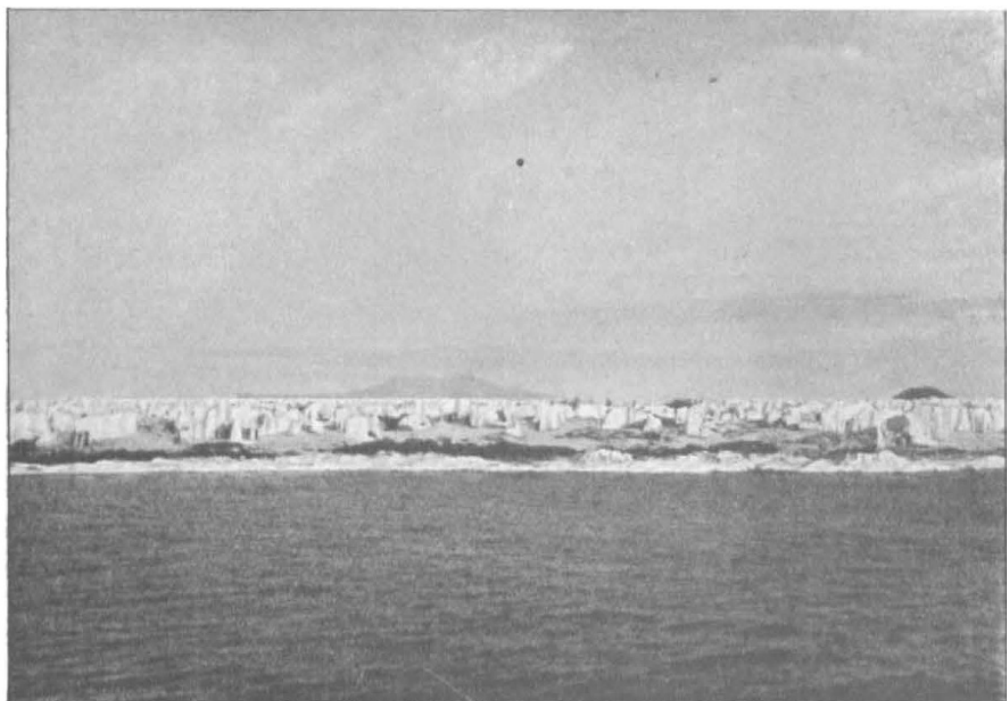

Frg. 3.-Pinnacled ice flozting in McMurdo Bay

made an addition to the list which Dr. Wilson thinks "will prove to be a wanderer from the Southern Ocean islands, representing the now rare sea-elephant of the M'Quaries." Dr. Wilson thinks little of the prospects of the Antarctic seal-fishery, notwithstanding the increased demand for skins of hair-seals, the chief

No. I 855 , VOL. 72$]$ reason being that few skins escape the unsightly scars inflicted by the killer whale. The expedition collected much valuable material with regard to doubtful species of birds, especially cases like the emperor and king penguins and the white-winged and roval albatrosses, where in the adults it is hard

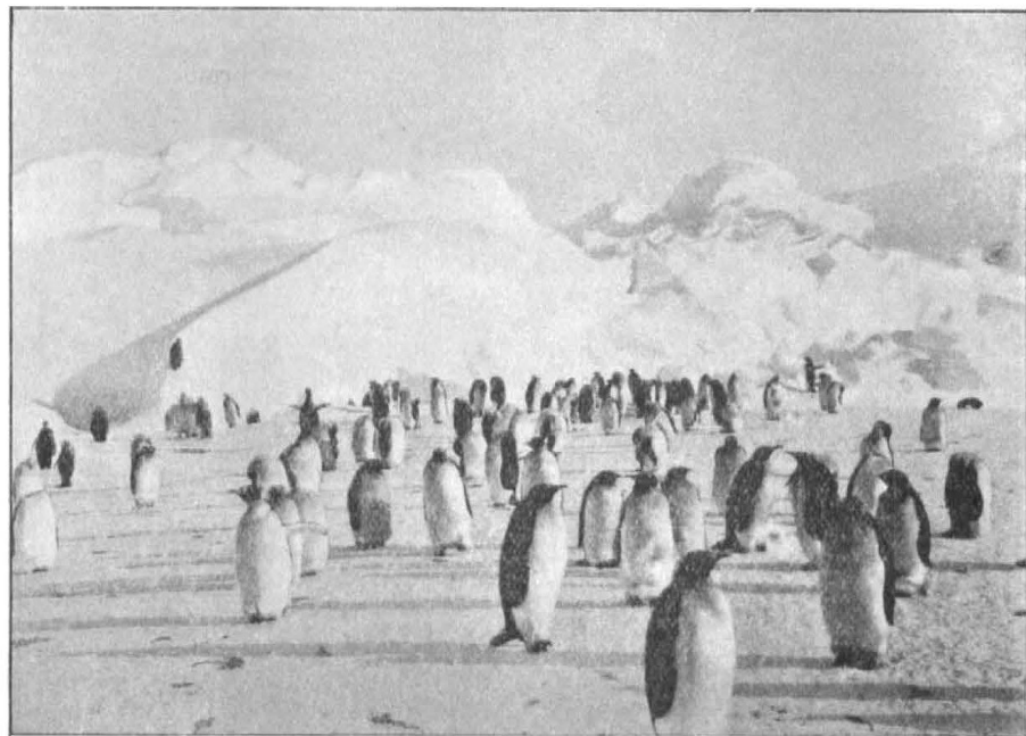

FIG. 4.-Emperor Penguin Rookery.

to find specific differences, although the chicks are quite distinct.

Perhaps the most significant point in Mr. Hodgson's report is that, contrary to expectation, it was found that outdoor biological work could be carried on all the year round, " and that even with comfort." As a result, a continuous daily routine left no time for examining the material collected. Everything goes to show that animal life is very abundant in the southern seas, and a predominant feature is the enormous quantity of sponges. One organism, regarded as a Nemertine, though suspected to be something else, appeared when it arrived frozen at the ship to be " close on 20 feet long, of a light brown colour, and about the diameter of an ordinary bootlace."

In summarising the observations on the sea ice, Captain Colbeck has " no hesitation in saying that the pack should be entered between long. $178^{\circ}$ and $180^{\circ}$ E., as early in December as possible."

THE STATE AND HIGHER EDUCATION.

MR. CHAMBERLAIN, in I moving a vote of thanks to the Lord Chancellor-who as Warden of the University of Birmingham gave an address in Birmingham on May $\mathrm{I}_{3}$-delivered a speech emphasising the importance to the nation of higher scientific education. During his remarks Mr. Chamberlain directed attention to the fact that the University of 